\title{
Modifying the Unified Theory of Acceptance and Use of Technology (UTAUT) Model for the Digital Transformation of the Construction Industry from the User Perspective
}

\author{
Thathsarani Hewavitharana ${ }^{1, *}$, Samudaya Nanayakkara ${ }^{2}$, Asoka Perera ${ }^{1}\left[\right.$ and Prasad Perera ${ }^{3}$ \\ 1 Faculty of Engineering, University of Moratuwa, Moratuwa 10400, Sri Lanka; asoka@uom.lk \\ 2 School of Engineering, Design and Built Environment, Western Sydney University, Penrith 2751, Australia; \\ s.nanayakkara@westernsydney.edu.au \\ 3 Nextec Engineering, Sri Jayawardenepura Kotte 10100, Sri Lanka; perera.prasad@gmail.com \\ * Correspondence: sachindrahewavitharana@gmail.com
}

\section{check for} updates

Citation: Hewavitharana, T.; Nanayakkara, S.; Perera, A.; Perera, P. Modifying the Unified Theory of Acceptance and Use of Technology (UTAUT) Model for the Digital Transformation of the Construction Industry from the User Perspective. Informatics 2021, 8, 81. https:// doi.org/10.3390/informatics 8040081

Academic Editors: Mahdi Safa and Maryam Hamidi

Received: 25 October 2021

Accepted: 18 November 2021

Published: 20 November 2021

Publisher's Note: MDPI stays neutral with regard to jurisdictional claims in published maps and institutional affiliations.

Copyright: (c) 2021 by the authors Licensee MDPI, Basel, Switzerland. This article is an open access article distributed under the terms and conditions of the Creative Commons Attribution (CC BY) license (https:// creativecommons.org/licenses/by/ $4.0 /)$.

\begin{abstract}
Inefficient and ineffective practices in the construction industry have hindered productivity even though it is considered as one of the largest sectors in any county. One best solution to overcome these inherent problems in the construction industry is to move forward with digital technologies. For that, organizational structure, technical aspects, and, most importantly, human factors need to be considered. The aim of this research is to find out human behaviors that affect the digital transformation of the construction industry based on the well-accepted model Unified Theory of Acceptance and Use of Technology (UTAUT). An in-depth literature review was carried out using fifty-five journal papers to develop a conceptual model for the acceptance of digital transformation, and it was validated and further reviewed using ten expert interviews. The model consists of seven constraints: Personal Benefits, Perceived Usefulness, Perceived Risk, Facility Conditions, Attitudes, and Subjective Norms. The analytical hierarchy process (AHP) was carried out to rank these seven factors according to individual priorities in the construction industry. Further, the model was extended and modified using factors derived from literature review and expert feedback. It is proved that "Perceived Personal Benefits" is the major consideration of an individual who is willing to move towards digital transformation. This research fulfills the lack of knowledge in the digitalization of the construction industry as per a human perspective, and it provides a prerequisite to finding the solutions for the issues which emerged within the industry towards digitalization. Further, the framework developed in the research can be used to systematically adopt the human factor for the digital transformation of the construction industry. In addition, this enables the analysis of changing demands for humans in digitally transformed environments, such as Industry 4.0 environments, and contributes towards a successful digital transformation that avoids the pitfalls of innovation performed without attention to human factors. The paper concludes by highlighting future research directions on the human factor in digital transformation as well as managerial implications for successful application in practice.
\end{abstract}

Keywords: analytical hierarchy process (AHP); construction industry; digital transformation; user behavior; UTAUT model

\section{Introduction}

After the third industrial revolution, many organizations have adopted digital transformation in order to stay competitive. Digital transformation is the realignment of new investments, technology, business models, and processes to drive new value for customers and employees. However, the construction industry, one of the highest contributors for any country's development index, productivity, in general, is largely left behind compared to other industries, such as manufacturing, automotive, and aviation, due to the slow digital 
transformation movement. Therefore, it is mandatory that the construction industry should move forward with digital transformation to boost its productivity [1-4].

However, a proper strategic plan should be implemented within the construction industry to have a successful digitalized environment. If one construction organization gets digitalized, the whole organization should focus on that, and a different strategy needs to be implemented [5-8]. Thus, organizational structure, technical aspects, and most importantly, the human factor need to be considered. Digitalized systems cannot improve organizational performance if they are not used; it is important to predict, explain, and increase user acceptance for the technologies $[9,10]$. Although the organization fulfills organizational and technical factors, none of the companies can move toward digitalization without human consideration. Therefore, it is necessary to understand the perception of individuals before implementing the digital transformation in any organization.

Unified Theory of Acceptance and Use of Technology (UTAUT) is a well-established model to explain the user intention to use an information system and usage behavior [10,11]. It is an evolution of another eight models, namely Innovation Diffusion Theory (IDT), Theory of Reasoned Action (TRA), Theory of Planned Behavior (TPB), the Social Cognitive Theory, the Motivational Model, the Model of Perceived Credibility (PC) Utilization, Technology Acceptance Models (TAM), and a hybrid model combining constructs from TAM and TPB [12]. Researchers have used this model to describe human behavior towards e-learning, e-governing, e-banking, and others [12-15]. Nevertheless, none have focused on construction digitalization and the human perspective towards digitalization using this UTAUT model. In addition, none of the above models can describe human behavior perfectly as the construction industry shows unique characteristics. Therefore, through this research, how the behavior and attitude of the user towards the use of new technology in construction industry is expected to be address.

\section{Background and Literature Review}

The construction industry is one of the largest industries with a high impact on the country's economy. However, its productivity is considerably low when compared to other industries [16]. Most of the people in the construction industry believe that digital technologies can bring out benefits in terms of efficiency and productivity to their organizations so that now the industry has leaped forward in its adoption of digital technology [17].

However, when it comes to the construction industry's digital transformation, the main key areas of digital transformation are required to be identified. As per the researchers conducted previously, the construction industry faces many challenges with digital technology implementations. Human resource is a main key area in this context. As human beings are not likely to change by nature, there is high resistance to switching from one system to another [13].

Further, the problems with digitalization are mainly due to the complex set of interdependent activities in construction [18,19]. In addition, the nature of construction presents problems not usually found in other industries. For example, construction differs widely from other industries due to the following features.

- Each project consists of unique characteristics;

- Internet access problems due to remote sites;

- Unpredictable nature of the project processes;

- Variation in the cost items according to the construction environment;

- Improper handling of resources and utilities;

- Innovations in the technical side are low;

- The quality of the product is primarily based on the workforce;

- Projects are heavily based on customer satisfaction.

All these issues make construction projects complex and difficult to monitor and control. With the development of infrastructure facilities, this situation is getting worse, and technological involvement is mandatory [20]. A number of models were proposed to 
analyze and utilize to enhance technology acceptance in any industry or domain. Therefore, the following sections describe the presently available established technology acceptance models.

\subsection{Theory of Reasoned Action (TRA)}

Theory of Reasoned Action (TRA) is a generalized theory designed to explain virtually any human behavior and was developed by Martin Fishbein and Icek Ajzen in 1991 [21,22]. According to the TRA, a person's performance of a specified behavior is determined by their behavioral intention (BI) to perform the behavior, and BI is jointly determined by the person's attitude (A) and subjective norms (SN). BI is a measure of one's intention to perform a specified behavior. Attitude toward behavior is defined as an individual's positive or negative feeling (evaluative effect) about performing the targeted behavior. Subjective norms mean the person's perception according to the people who are around him and important to him [23]. According to TRA, a person's attitude towards a behavior is determined by their salient beliefs regarding the consequences of performing the behaviors and evaluation. The attitudes are influenced by two factors: strength of behavioral beliefs (e.g., whether or not the outcome is probable) and the evaluation of the potential outcomes (e.g., whether or not the outcome is positive). However, any attitude regarding certain behavior may be positive, negative, or neutral. This theory empathizes that there is a direct relationship between the attitudes and their outcome [24]. If one believes that there will be a favorable outcome and there is a high probability of it, then they are more likely to accept the technology.

The other joint component for behavioral intention is the "Subjective Norms". It empathizes the impact of external relevant group members on the performance behavior of a person. As per the definition of Ajzen [21], the subjective norm is the "Perceived social pressure to perform or not to perform the behavior". "Nominative beliefs" and "Motivation to comply" are the two fundamental determinants of subjective norms of any behavioral intention [21]. Nominative beliefs shape a person's perception to perform the task or not to perform the task with the perception of close relative groups.

Furthermore, "Motivation to comply" adds additional value to one's perception of a certain behavior. It addresses the fact that specific individuals may or may not comply with other social groups they may accept the social pressure or resist the social pressure. Behavioral intention is the function of both "attitude towards behavior" and "Subjective Norm" toward that behavior. "Attitude toward behavior" shows how strong an individual holds his attitude toward the action, and "Subjective Norm" represents how the external parties influence the intention [25].

However, TRA does not consider external conditions, which are the performance of behavior, such as specific opportunities, skills, conditions, and resources. Further, attitude and behavioral intention are always directly connected with the actual behaviors when the cognitive effort is lower. Due to some circumstances, attitude does not always comply with the actual behavior [26]. For minimizing these drawbacks, the conceptual model was developed by considering two additional variables called "Perceived Personal Benefits" (POB) and "Attitudes Towards Digitalization" (AD) because it is necessary to consider inherent human beliefs and other external factors, such as perceived other benefits, skills, and conditions, when implementing within the construction organizations [27].

\subsection{Theory of Planned Behavior (TPB)}

Icek Ajzen proposed the theory of planned behavior (TPB) as an extension of TRA with some modifications [21]. It consists of three components, namely "Behavioral beliefs", "Nominative beliefs", and "Control beliefs" [28]. These represent the users' core beliefs towards the outcomes of the actions, the influence of other external parties, and the control over the result of the behavior. Behavioral beliefs, or the attitude of an individual, have a strong influence on the actual behavior of an individual. If the expected outcome is favorable with a positive attitude, it increases the likelihood of actual performance [29]. 
Nominative beliefs are considered as the other interferences from external parties. The critical fact is the level of importance that the individual pays to these external parties' expectations.

This newly added factor, "Perceived Behavioral Control", refers to the degree to which a person believes that they can control any given behavior. This perceived behavioral control consists of two dimensions, namely self-efficacy and controllability [30]. Selfefficacy refers to the difficulty required to perform the behavior or the ability to succeed with that behavior. Controllability refers to the outside factors to control the behavior. If an individual has the power to control the performance of the behavior and they have enhanced confidentiality over the success of the behavior, then there is a high probability of performing that specific task [27].

The resulting behavior of an individual is based on their perceived behavioral control. There are two types of control over the acceptance, namely internal control and external control. "Internal control" refers to how the individual sees themself as being in control when performing the specific behaviors according to their knowledge, skills, and abilities [30,31]. External controls, such as approval from related parties, will shape individual beliefs. Time is another factor that will impact one's level of behavioral control. Therefore, control beliefs can be named as the factor which will dictate the perceived behavioral control.

When all three beliefs are combined, and if both attitudes and subjective norms are positive and there is a strong trust in the performance of the specific behavior, then it is bound to strengthen the individual intention and resolve toward the actual behavior. Thus, TPB has acquired more value than TRA. However, the main argument against TPB is not considering "human emotions" surrounding the behavior [31].

\subsection{Technology Acceptance Model (TAM)}

Davis Fred et al. [27] developed the technology acceptance model in 1989 to predict an individual's use and acceptance of information systems and technology. It is one of the major models that came across with the extension of TRA developed by Fred Davis and Richard. The importance of TAM is that it is specifically designed to address the acceptance of IS technology [32]. Furthermore, it is seen that the TAM model is much simpler than the primary two models TRA and TPB. TAM consists of two main concepts "Perceived Usefulness" and "Perceived Ease of Use". Perceived Usefulness defines as the "degree to which a person would think that particular system would enhance his or individual job performance" [33]. Perceived Ease of Use refers to "the degree to which a person believes that using a particular system would be free of effort" [34]. These two factors are influenced by external factors, such as social factors, cultural factors, and political factors. Language, skills, and facilitating conditions are the main concerns in social factors, while political factors consist of politics and political crisis. The "attitudes" refers to the user's evaluation of employing a particular technology, while "Behavioral intention" is the measure of the likelihood of a person using the technology [35]

Many researchers have used TAM to describe different types of information systems. For example, E-learning systems by teachers, online shopping acceptance, acceptance of e-commerce, online banking systems, e-service adoption, acceptance of Radio Frequency Identification (RFID) used TAM and modified TAM models to describe the user behavior $[27,36,37]$.

However, as mentioned above, the TAM model does not consider the barriers that would interfere with the usage of a particular information system. Further, it does not cooperate with other variables, such as system design characteristics, top management support, training for staff, and decision-making characteristics [38].

\subsection{Combined TAM and TPB}

TAM is considered a model recognized and supported by many researchers to identify the use of technology and its behavioral intentions. Even though the TAM model does not 
consider social factors and control factors, there is a direct effect on behavioral changes by these two factors. Therefore, Taylor and Todd added the elements of the TPB to the TAM and created an integrated model called C-TAM-TPB [39].

The main feature of this model is the variation between intention and behavior, which allows the application of this model to both people who are familiar with technologies and those who are not. Moreover, as the subjective norms and perceived behavioral control factors are included in this model, it allows a better interpretation for the acceptance of technology than individual TAM or TPB models [40].

\subsection{Social Cognitive Theory}

Social Cognitive Theory explains how the behavior of a person is changed by personal factors and the environmental condition of the individual. It consists of three main components, namely behavior, personal factors, and environmental influences, which are interrelated [41]. When considering the interrelationship between personal factors and behavior, personal factors, such as expectations, beliefs, self-perceptions, goals, and intentions, give shape and direction to the behavior. On the other hand, the environment and personal factor interrelationship shows how personal factors, such as human expectations, beliefs, emotional benefits, are modified with the social influences. Human beings' reactions are evoked by social environments, such as age, size, race, sex, and physical attractiveness [42].

Furthermore, according to the social cognitive theory, there is an interrelationship between behavior and the environment. In the transactions of everyday life, behavior alters environmental conditions, and environmental conditions alter behaviors. For example, if the external environment is based on traditional approaches with a technology resistive top management, it is unlikely to have an individual move with innovations [43]. So, the behavior of that individual is affected by the external working environment.

\subsection{Diffusion Innovation Theory}

The Diffusion Innovation Theory (DIT) could be considered as one of the most popular theories that have attempted to explore factors that affect an individual to adopt an innovation or a new technology. It suggests the relationship between the characteristics of the innovations and their adoption [44]. The adoption is measured in terms of compatibility, relative advantage and complexity, compatibility, trialability, and observability. It explains how, why, and at what rates new ideas and technologies will spread throughout the cultures [45].

- $\quad$ Compatibility: The degree to which an innovation is perceived as relatively difficult to understand and use;

- Relative advantage: The degree to which an innovation is perceived as being better than the idea it supersedes;

- Complexity: The degree to which an innovation is perceived as relatively difficult to understand and use;

- Trialability: The degree to which an innovation may be experimented with on a limited basis;

- $\quad$ Observability: The degree to which the innovations are observer able by others.

Further, DIT has defined adopted categories: innovators, early adopters, early majority, late majority, and laggard.

Innovators: Innovators are the people who are willing to take risks with the highest social status and who have the closest connection with scientific research sources. Therefore, innovators should have the capacity to absorb any failure due to the drawback of an innovation $[45,46]$.

Early adopters: These individuals have more leadership opinions and discrete adoption choices than innovators. They engage much earlier than late adopters and can bear any loss financially [45]. 
Early Majority: Early majority take significantly longer than early adopters, and they take action after verifying the results of innovators and early adopters. However, the early majority keeps contact with early adopters [44,46].

Late Majority: These are the average type of people in society. They accept innovations after the majority of society has adopted the innovation. They use the system after the risk and failures have been prevented [44,46].

Laggards: These people show little or no leadership qualities. Most of them follow traditional methods and are unlikely to deviate from their mindset [44].

\subsection{Model of PC Utilization}

In 1977, Triandis built the theory of attitude and behavior, which distinguished between cognitive and affective components of attitude [22]. Beliefs are incorporated with the cognitive components of attitudes. According to Triandis, "Behavior is determined by what people would like to do (attitude), what they think they should do (Social norms), what they have usually done (habits), an expected consequence of their behavior" [22].

However, in 1991 Thompson and the team has reformed the model to predict personal computer utilization. In addition to the components in Triandis' attitude and behavioral model, Thompson included the "Job-Fit: the extent that an individual may enhance his/her job performance", "Complexity: the extent to which a technology will be easy to understand and use", "Long-term consequence: the outcomes which will be created due to the behavior ", "Affect towards use: the feelings with the use of technology", "Social factors: social influences towards the utilization of technology", and "Facilitating conditions: the existence of resources, technical capacities, support from the users for the utilization of technologies" [47]. However, due to measurement difficulties, the "habit" factor was excluded from the model. Due to that, the model examines only the social factors, complexity, job-fit, long-term consequences, affect towards use, and facilitating conditions.

\subsection{Motivational Model}

In 1992, Davis, Bagozzi, and Warshaw tested motivational models based on extrinsic and intrinsic motivations and found their effect on the individual's intention to perform behavioral technology usage [48]. In the model, extrinsic motivation referred to the anticipated reward after the usage, and intrinsic motivation referred to the perceived enjoyment of using the technology regardless of the performance outcome.

The model implies that people's intention to use computers in the workplace is mainly influenced by how helpful the computers are for improving their job performance and the degree of enjoyment individuals experience using them [49]. The study of this model further identified that the capacity of enjoyability that can be achieved through technology might enhance the acceptance rate unless it does not affect the system's usefulness [50]. Incentive properties of anticipated enjoyment and normative social pressures have enhanced the usage of technology. In addition, factors, such as skills, organizational support, and usage, also stimulate technology usage [51].

\subsection{Unified Theory of Acceptance and Usage of Technology (UTAUT) Model}

Venkatesh et al. [52] created the Unified Theory of Acceptance and Usage of Technology model in 2003, eliminating the drawbacks of the TAM model, and it incorporates social factors and human behaviors. It also identifies the critical factors for ICT acceptance with behavioral intention to use the technology and the actual usage [53]. It has been found that TAM and its extensions can only predict up to $40 \%$, while UTAUT can predict $70 \%$ of technology acceptance [54]. UTAUT was developed based on four determinants, namely: Perceived Usefulness (PU), Perceived Ease of use (PE), Subjective Norms (SN), and Facilitating Conditions (FC) $[31,55,56]$.

- Perceived Usefulness (PU) - the individual believes that system will help them to do better with their jobs; 
- $\quad$ Perceived Ease of Use (PE) - how easy an individual believes the system will be to help them to do their jobs;

- Subjective Norms (SN) — whether the individual is concerned about external parties' opinion;

- Facilitating Conditions (FC) — whether the individual has the personal knowledge and institutional resources.

In addition to the basic four factors, the UTAUT model introduced stimuli that impact the acceptance of technologies [57,58]. Gender, Age, Experience, Voluntariness of use are considered the stimuli in the UTAUT model. The combination of all these factors explains the perception of the human being towards the acceptance of new technologies [59].

\subsection{Model Evaluation, Requirements, and Constraints in the Construction Industry}

The acceptance of technology has been heavily studied by management information system (MIS) researchers. Coinciding with the rise in personal computers in the 1980s, issues associated with the acceptance of this emergent technology began receiving research attention. Influenced by the theory of reasoned action, the authors of [24,27] suggest that two beliefs are essential for one's attitude toward the usage of computers: perceived usefulness (to what extent a person believes using a computer could enhance their job performance) and perceived ease of use (to what extent a person believes using a computer could be free of effort).

The model created by Venkatesh et al. [52] has been utilized in the study of many types of technology acceptance, ranging from Chen, who tested the applicability of the UTAUT model in playing online games through mobile phones, to [31], which explained the intention to adopt accounting software by using the UTAUT model [41].

Theories used to create the UTAUT draw upon the theory of reasoned action (TRA), the technology acceptance model (TAM), the motivational model (MM), the theory of planned behavior (TPB), the combined TAM-TPB model, the model of PC utilization (MPCU), the IDT, and the social cognitive theory (SCT), as explained above. In constructing the UTAUT model, Venkatesh tested all of these constructs and combined them to form a set of new and refined factors that affect Behavioral Intention and User Behavior of information [52].

However, the limitation of the model is that it is primarily based on theories constructed for voluntary environments where users can decide on the use of the system [59]. However, the decision of adoption and use of technologies across the construction industry is often decided at an organizational or project level, making the use of emerging technologies, such as BIM, mandatory at the individual level. Furthermore, the strict mandatory settings evinced within construction organizations may not be appropriate with the UTAUT model. Furthermore, according to Gunasinghe and Nanayakkara [37], human resistance is the second most important contributor to time and budget overruns and the fourth most important barrier to implementation. Therefore, it is mandated to adopt a flexible model for the technology acceptance construction industry considering the inherent characteristics that prevail in the construction sector.

\section{Methodology}

An in-depth literature review was carried out to develop the conceptual model for the digitalization of the construction industry. The conceptual model was derived from the Unified Theory of Acceptance and Use of Technology (UTAUT) model, which is well established in human behavior in the technology acceptance arena. UTAUT is the latest theory that aims to explain the user intention and use of information systems [60]. Therefore, the UTAUT model was recognized as the best model to determine how construction industry people accept digitalization. However, the literature review was done based on UTAUT, and the other eight models (Technology Acceptance Model (TAM), Diffusion Innovation Theory (DIT), Theory of Reasoned Action (TRA), Theory of Planned Behavior (TPB), Social Cognitive Theory (SCT), Model of PC Utilization (MPU), Motivational Model (MM), Combined TAM and TPB) as UTAUT is built on them. Fifty-five journal articles 
in Science Direct, Google Scholar were selected for the literature review, and the factors gained from each article were summarized as per Appendix A.

After reviewing further, the factors were aligned into seven primary constructs namely, "Perceived Usefulness (PU)", "Perceived Ease of Use (PE)", "Personal Attitude towards digitalization (AD)", "Facility Conditions (FC)", "Perceived Personal Benefits (PB)", "Subjective Norms (SN)", and "Perceived Risk (PR)". At the initial stage, the effect from each factor was considered to be the same for the digitalization; however, it was not. Therefore, in-depth semi-structured interviews were conducted by utilizing these seven criteria to weight them based on the analytic hierarchy process (AHP) method. Ten construction digitalization experts were interviewed with a questionnaire in face-to-face sessions of less than one hour.

Within the first ten minutes, the objectives of the interview and the basic idea of the research were explained. Then the questionnaire was distributed. Both open-ended and Likert scale (Point 1-7) questions were included in the questionnaire. The questionnaire structure was based on the analytic hierarchy process (AHP) [61,62]. A sample of the expertise interview is mentioned in Table 1. Data analysis was carried out using the AHP technique (pairwise comparison) $[63,64]$, and the constraints were prioritized as per the impact on the digitalization of the construction industry according to the expert judgments.

Table 1. Expert interview details.

\begin{tabular}{|c|c|c|c|c|c|}
\hline & Designation & Organization Type & Experience (Years) & Expert Area & Interview Time \\
\hline 1 & Director & $\begin{array}{l}\text { Global management } \\
\text { consulting firm }\end{array}$ & Above 10 & $\begin{array}{l}\text { SAP ERP implementation, } \\
\text { Internet of Things (IoT), } \\
\text { Smart devices }\end{array}$ & $45 \mathrm{~min}$ \\
\hline 2 & $\begin{array}{l}\text { Commercial } \\
\text { Manager }\end{array}$ & $\begin{array}{c}\text { International } \\
\text { construction IT } \\
\text { solution provider }\end{array}$ & Above 10 & $\begin{array}{l}\text { BIM implementation, } \\
\text { Robotics }\end{array}$ & $20 \mathrm{~min}$ \\
\hline 3 & ERP Developer & $\begin{array}{l}\text { Construction IT } \\
\text { solution provider }\end{array}$ & 5 & $\begin{array}{l}\text { webERP implementation, } \\
\text { EDMS }\end{array}$ & $45 \mathrm{~min}$ \\
\hline 4 & ERP Executive & $\begin{array}{c}\text { Large scale } \\
\text { construction company }\end{array}$ & 2 & $\begin{array}{c}\text { webERP implementation, } \\
\text { EDMS }\end{array}$ & $45 \mathrm{~min}$ \\
\hline 5 & MIS Consultant & $\begin{array}{l}\text { Higher education } \\
\text { institution }\end{array}$ & 10 & $\begin{array}{c}\text { MIS, } \\
\text { SAP and webERP } \\
\text { implementations, Asset } \\
\text { Management }\end{array}$ & $45 \mathrm{~min}$ \\
\hline 6 & $\begin{array}{l}\text { Management } \\
\text { Consultant }\end{array}$ & $\begin{array}{l}\text { Global management } \\
\text { consulting firm }\end{array}$ & 5 & $\begin{array}{l}\text { 5D BIM, Internet of Things } \\
\text { (IoT) }\end{array}$ & $25 \mathrm{~min}$ \\
\hline 7 & $\begin{array}{l}\text { Management } \\
\text { Consultant }\end{array}$ & $\begin{array}{l}\text { Global management } \\
\text { consulting firm }\end{array}$ & 3 & $\begin{array}{l}\text { Risk Management, } \\
\text { Organizational } \\
\text { Transformation }\end{array}$ & $20 \mathrm{~min}$ \\
\hline 8 & ERP executive & $\begin{array}{c}\text { Large scale } \\
\text { construction company }\end{array}$ & 2 & ERP implementation & $30 \mathrm{~min}$ \\
\hline 9 & Technical Director & $\begin{array}{l}\text { International ERP and } \\
\text { supply chain solution } \\
\text { provider }\end{array}$ & Above 10 & $\begin{array}{c}\text { ERP, Asset Management, } \\
\text { Service Management, } \\
\text { Document Controlling, } \\
\text { Quality and Safety } \\
\text { Measures }\end{array}$ & $30 \mathrm{~min}$ \\
\hline 10 & $\begin{array}{l}\text { Engineering } \\
\text { Consultant }\end{array}$ & $\begin{array}{l}\text { National } \\
\text { telecommunication } \\
\text { provider }\end{array}$ & 5 & Digitalization expert & $25 \mathrm{~min}$ \\
\hline
\end{tabular}


Then, the literature review was extended to determine the associated factors for each conceptual design constraint. Further, qualitative analysis was done with the experts feedback, and the conceptual model was improved based on the feedback.

\section{Results and Analysis}

\subsection{The Conceptual Model}

This research developed a conceptual model (See Figure 1) that explains human behavior for the construction industry's digital transformation. It was built from literature with eight models Theory of Reasoned Action (TRA), Theory of Planned Behavior (TPB), Technology Acceptance Model (TAM), C-TAM-TPB, Motivational model, Social cognitive theory, Diffusion Innovation Theory (DIT), Model of PC utilization and their derivative Unified Theory of Acceptance and Use of Technology (UTAUT) model. Derivation of the conceptual model using literature is shown in Appendix A and Table 2.

Table 2. Deriving factors for the conceptual model.

\begin{tabular}{|c|c|c|}
\hline Factors & Derivation & Definition \\
\hline Perceived Usefulness & \multirow{3}{*}{ Perceived Usefulness (PU) } & \multirow{3}{*}{$\begin{array}{l}\text { PU measures the degree to which an individual } \\
\text { believes that using the technology will help them } \\
\text { attain benefits. } \\
\text { This is directly connected with the person's task. }\end{array}$} \\
\hline Relative Advantage & & \\
\hline Perceived Enjoyment & & \\
\hline Perceived Ease of Use & \multirow{3}{*}{ Perceived Ease of Use (PE) } & \multirow{3}{*}{$\begin{array}{l}\text { PE is the degree of ease associated with } \\
\text { customers' use of technology. }\end{array}$} \\
\hline Complexity & & \\
\hline Perceived Enjoyment & & \\
\hline Social Factors & \multirow{5}{*}{ Subjective Norms (SN) } & \multirow{5}{*}{$\begin{array}{c}\mathrm{SN} \text { is defined as "a person's perception that most } \\
\text { people who are imported to him think he should } \\
\text { or should not perform the behaviour in } \\
\text { question". }\end{array}$} \\
\hline Political Factors & & \\
\hline Top Management Effectiveness & & \\
\hline Top Management Support & & \\
\hline Cultural Factors & & \\
\hline Observability & \multirow{5}{*}{ Perceived Personal Benefits (PB) } & \multirow{5}{*}{$\begin{array}{l}\text { POB measures the degree to which an individual } \\
\text { believes that using technology will help him } \\
\text { attain benefits that are not related to the task. }\end{array}$} \\
\hline Trialability & & \\
\hline Demonstratebility & & \\
\hline Perceived Credibility & & \\
\hline Personal Development & & \\
\hline System Design Characteristics & \multirow{6}{*}{ Facility Conditions (FC) } & \multirow{6}{*}{$\begin{array}{l}\text { The degree to which an individual believes that } \\
\text { an organizational and technical infrastructure } \\
\text { exists to support the use of the system. }\end{array}$} \\
\hline Training & & \\
\hline Decision Making Characteristics & & \\
\hline Management Effectiveness & & \\
\hline Program Effectiveness & & \\
\hline Skill/Education Level & & \\
\hline Perceived Risk & \multirow{6}{*}{ Perceived Risk (PR) } & \multirow{6}{*}{$\begin{array}{l}\text { Perceived risk is the uncertainty associated with } \\
\text { purchasing and maintaining. }\end{array}$} \\
\hline Barriers to Implement & & \\
\hline Long term Consequence & & \\
\hline Cost of Technology & & \\
\hline Perceived Behavioral Control & & \\
\hline Task Technology Fit & & \\
\hline
\end{tabular}


Table 2. Cont.

\begin{tabular}{|c|c|c|}
\hline Factors & Derivation & Definition \\
\hline Motivation Towards Usage & \multirow{7}{*}{ Behavioral Intention } & \multirow{7}{*}{$\begin{array}{l}\text { The individual's positive or negative feelings, } \\
\text { environment factors, facilities, benefits, and other } \\
\text { factors affect behavior intention. }\end{array}$} \\
\hline Perceived Usefulness & & \\
\hline Perceived Ease of Use & & \\
\hline Subjective Norms & & \\
\hline Personnel Benefits & & \\
\hline Availability of Facilities & & \\
\hline Attitude Towards Digitalization & & \\
\hline Availability of Facilities & \multirow{2}{*}{ Actual Usage } & \multirow{2}{*}{$\begin{array}{l}\text { The measure of one's actual behavior to perform } \\
\text { a specified usage behavior. }\end{array}$} \\
\hline Behavioral Intention & & \\
\hline
\end{tabular}

The factors mentioned in Appendix A were adjusted and summarized into seven factors, namely Perceived Usefulness (PU), Perceived Ease of Use (PE), Subjective Norms (SN), Perceived Personal Benefits (PB), Facility Conditions (FC), Perceived Risk (PR), and Personal Attitude towards digitalization (AD) (Refer Table 2).

\subsection{Factors Affecting for Digitalization of the Construction Industry \\ Perceived Usefulness (PU)}

Performance Usefulness (PU) is defined as "the degree to which an individual believes that using the system will help him/her attain gains in job performance". It has been proven by many researchers that there is a significant influence on behavioral intention to use [65]. Similarly, in the context of digitalizing the construction industry, if the user thinks that the technology helps gain job performance, they will be more likely to accept it. Therefore, it can be hypothesized that Perceived Usefulness (PU) significantly influences users' intention towards digitalization [32].

\section{Perceived Ease of Use (PE)}

Perceived Ease to Use (PE) is defined as "the degree of ease associated with the use of the system, and UTAUT has identified that it is an important factor that affects behavioural intention to accept the technology" [53]. In the construction industry, if the digitalization technologies are complex to operate, then industrial people may not like to implement the systems in their organizations. Therefore, it is necessary to identify whether there is a positive influence on user behavior from the easiness/difficultness of the system [32].

\section{Subjective Norms (SN)}

Subjective Norms/Social Influence is defined as "the degree to which an individual perceives that importance of other's belief he/she should use to accept the new system" [66]. In addition to the UTAUT model, many other researchers have found a high positive effect on behavioral intention to use [42]. Therefore, it is necessary to capture whether this social influence is a determinant of the digitalization of the construction industry.

\section{Perceived Personal Benefits (PB)}

Perceived Personal benefit is defined as "the degree to which an individual believes that using the system will help him/her attain personal benefits within his job role" [22]. For example, if an individual can achieve promotions or rewards, he/she tends to use the systems. Therefore, if digitalization is introduced to the construction industry, he/she may look for other benefits.

In this conceptual model, the motivational model is attached to Perceived Usefulness, Perceived Ease of Use, Subjective Norms, and Perceived Personal Benefits. In there, Perceived Usefulness and Perceived Ease to Use belong to the intrinsic motivation and Subjective Norms and Perceived Other Benefits belong to the eccentric motivation factors. 


\section{Facility Conditions (FC)}

Facility condition is defined as "the degree to which an individual is satisfied with the resources and facilities required by the technology". Knowledge, Hardware/Software, Technical expert, Top management support are some of the facilitating conditions related to the digitalization of the construction industry [67]. Therefore, it can be identified that there is a significant relationship between facility conditions and the digitalization of the construction industry.

\section{Perceived Risk (PR)}

The construction industry is associated with high risks because of its unique characteristics. Therefore, it is necessary to consider the risk associated with technology acceptance along with the digital transformation. If an individual knows that there is a high risk of attaining the benefits from digitalization, then there is a low probability of transforming the industry towards digitalization $[68,69]$

\section{Attitude towards Digitalization (AD)}

Individual Attitudes are "the thinking inherent to a person from the background nature". Whatever is said and done, if the individual has a traditional mindset, they may resist changing with the digital transformation, and there should be a proper strategy to change this kind of mindset to switch them toward digital technologies [51]. Thus, it can be hypothesized that there is a positive relationship between the perceived individual attitude and the digitalization of the construction industry.

\subsection{Prioritizing the Factors Based on Analytic Hierarchy Process (AHP)}

After developing the conceptual model (See Figure 1), weights were given to each constraint based on expert judgments using the seven-point Likert scale according to the AHP structure (Refer Table 3).

Table 3. Pairwise comparison for each constraint using the seven-point Likert Scale.

\begin{tabular}{|c|c|c|c|c|c|c|c|}
\hline & $\begin{array}{l}\text { Personnel } \\
\text { Benefits }\end{array}$ & Usefulness & $\begin{array}{l}\text { Perceived } \\
\text { Risk }\end{array}$ & $\begin{array}{l}\text { Facility } \\
\text { Condition }\end{array}$ & $\begin{array}{l}\text { Easy to } \\
\text { Use }\end{array}$ & $\begin{array}{c}\text { Attitude } \\
\text { towards } \\
\text { Digitalization }\end{array}$ & $\begin{array}{l}\text { Subjective } \\
\text { Norms }\end{array}$ \\
\hline $\begin{array}{l}\text { Personnel } \\
\text { Benefits }\end{array}$ & 1 & 5 & 3 & 4.00 & 4 & 4 & 7 \\
\hline Usefulness & 0.20 & 1.00 & 0.60 & 0.80 & 0.80 & 0.80 & 1.40 \\
\hline Perceived Risk & 0.33 & 1.67 & 1.00 & 1.33 & 1.67 & 1.67 & 2.38 \\
\hline $\begin{array}{l}\text { Facility } \\
\text { Condition }\end{array}$ & 0.25 & 1.25 & 0.75 & 1.00 & 1.25 & 1.25 & 1.75 \\
\hline Easy to Use & 0.25 & 1.25 & 0.60 & 0.80 & 1.00 & 0.33 & 3.00 \\
\hline $\begin{array}{c}\text { Attitude towards } \\
\text { Digitalization }\end{array}$ & 0.25 & 1.25 & 0.60 & 0.80 & 3.00 & 1.00 & 3.00 \\
\hline $\begin{array}{l}\text { Subjective } \\
\text { Norms }\end{array}$ & 0.14 & 0.71 & 0.42 & 0.57 & 0.33 & 0.33 & 1.00 \\
\hline
\end{tabular}

During the comparison, the consistency ratio was recorded as $0.026836<0.1(n=7$, Random index 1.32, Consistency index $=0.035423$ ), which allowed continuing with AHP. After analyzing the criteria, seven weights criteria were ranked (See Table 4) 
Table 4. Prioritizing the constraints.

\begin{tabular}{ccc}
\hline Constraint & Weightage Percentages & Rank \\
\hline Perceived Personal Benefits (PB) & 40 & 1 \\
\hline Perceived Usefulness (PU) & 14.2 & 2 \\
\hline Perceived Risk (PR) & 12.67 & 3 \\
\hline Facility Conditions (FC) & 10.68 & 4 \\
\hline Perceived Ease of Use (PE) & 9.28 & 5 \\
\hline Attitude Towards Digitalization (AD) & 8.00 & 6 \\
\hline Subjective Norms (SN) & 5.04 & 7 \\
\hline
\end{tabular}

\section{Discussion}

Now is the best time for the construction industry to digitalize its operations as every other industry is moving fast towards Industry 4.0 [68,70]. However, it is showing a tepid journey toward digitalization because of the human factor involved. Therefore, it is mandatory to find out why individuals in the construction industry resist this. The conceptual model for the acceptance of technology was developed based on eight models Theory of Reasoned Action (TRA), Theory of Planned Behavior (TPB), Technology Acceptance Model (TAM), C-TAM-TPB, Motivational model, Social cognitive theory, Diffusion Innovation Theory (DIT), Model of PC utilization and their derivative Unified Theory of Acceptance and Use of Technology (UTAUT) model.

After developing the basic conceptual model, as per Figure 1, the model was extended by embedding factors from a comprehensive literature review and expert interviews, as per Table 5. Interviewee 2 and Interviewee 5 suggested, "Breaking long term established habits" and "The state-of-the-art technology (How smart the technology)" would affect the acceptance of technology. These two factors were in line with the factor "Inherent characteristics" and "Satisfaction level of the user", which were already found through the literature. Further, Interviewee 1 mentioned that "The ability of the error recovery" would affect some users to accept the technology. As it was not found through literature, it was included as a new factor for the conceptual model. According to Interviewee 2 and Interviewee 10, "Computer Literacy" and "Experience from previous task" were two other factors that would influence digitalization acceptance. However, as these two factors were already included in the conceptual model as "Knowledge" and "Experience", no further adjustments were made to the model. Interviewee 3 and Interviewee 7 mentioned that "Change in the job role/job replacement" and "Change in working place" were two other considerations of humans when they move on to digitalization. As those two factors were considered with "Job security" in the model, no change was made to the original model. Interviewees 5 and 9 said that "Force from top management" could speed up this digitalization journey. Once the top management imposed rules and regulations to smooth up the operations, the workforce needed to move on. Interviewee 4 revealed that it was necessary to change up the mindset of the construction people. 


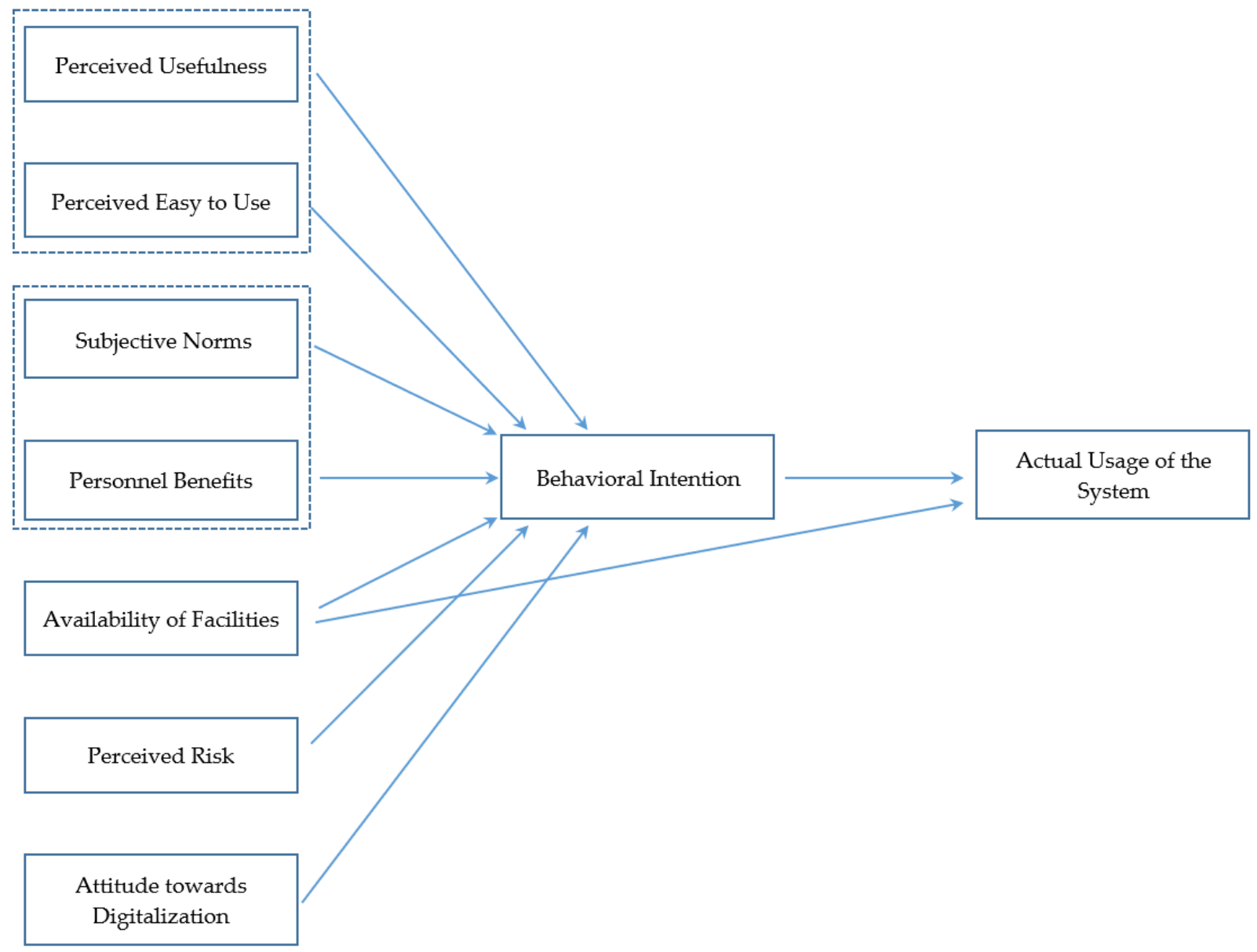

Figure 1. The conceptual model for digitalization of the construction industry.

Table 5. Deriving factors to extend the conceptual model.

\begin{tabular}{|c|c|c|}
\hline Constraint & Components & References \\
\hline \multirow{3}{*}{ Perceived Usefulness } & Accuracy & {$[14,71]$} \\
\hline & Time & [14] \\
\hline & Quality & [71] \\
\hline \multirow{5}{*}{ Perceived Ease of Use } & Effort to use & [72] \\
\hline & Satisfaction level & [14] \\
\hline & Flexibility & [14] \\
\hline & Dependence over manual & [14] \\
\hline & Error Recovery & Expert Interview \\
\hline \multirow{4}{*}{ Subjective Norms } & Peer pressure & [66] \\
\hline & $\begin{array}{l}\text { Regulations and low of the } \\
\text { company }\end{array}$ & [73] \\
\hline & Top management perspective & [71] \\
\hline & Social network configuration & [66] \\
\hline \multirow{4}{*}{ Perceived Personal Benefits } & Productivity & {$[74]$} \\
\hline & Performance Level & [75] \\
\hline & Level of goal achievement & [58] \\
\hline & Job security & [76] \\
\hline
\end{tabular}


Table 5. Cont.

\begin{tabular}{|c|c|c|}
\hline Constraint & Components & References \\
\hline \multirow{5}{*}{ Facility Conditions } & Financial Capacity & [76] \\
\hline & Training & [71] \\
\hline & Resources & [71] \\
\hline & Knowledge & [71] \\
\hline & IT support & [71] \\
\hline \multirow{5}{*}{ Perceived Risk } & Compatibility & [71] \\
\hline & Nature of the industry & [68] \\
\hline & Control behavior & [59] \\
\hline & Long term consequences & [77] \\
\hline & Cost of the investment & [78] \\
\hline \multirow{7}{*}{$\begin{array}{l}\text { Attitude towards } \\
\text { Digitalization }\end{array}$} & Income & [76] \\
\hline & Inherent Characteristics & [14], Expert Interview \\
\hline & Educational Background & [31] \\
\hline & Age & [58] \\
\hline & Experience & [71] \\
\hline & Profession & [59] \\
\hline & Culture & Expert interview \\
\hline
\end{tabular}

Further, he said that most people were afraid of tracing their working records using digital technologies. So that, they tried to discontinue the use of those devices. Therefore, it proved that the "Inherent characteristics" of the people matter for digitalization. Furthermore, Interviewee 5 explained that there is an impact from the culture for this digitalization, and it was included for the model as a new variable.

\section{Derivation of Factors to Extend the Conceptual Model}

As described above, factors were identified for each constraint using the literature review and expert interviews. The detailed summary is mentioned in Table 5. Further, the graphical model represents in Figure 2.

Initially, the above seven constraints were considered to impact digitalization equally; however, they did not. Therefore, according to the expert judgments, those factors were ranked with analytic hierarchy process (AHP) analysis. As per the results of AHP, the Personal factor was the highest factor that affects digitalization. Once the individual receives personal benefits from any activity, they may tend toward it. If individuals understand that digitalization may upgrade their carrier and potential, they will move towards digitalization, although they are restricted with their inherited characteristics. Therefore, it is essential to empathize the benefits of digitalization in a specific manner (e.g., workshop, rewarding system, ranking system) to the employees in a construction organization before doing the digital transformation. In addition, a proper post-implementation consulting service should be established. Vendors of technologies should contribute their services before implementation, with implementation, and after implementation. "Perceived Usefulness" is the next major constraint for digital transformation. These two main constraints prove that people will be motivated towards digital transformation dependent on the benefits they achieve personally. Therefore, most importantly, people should empathize with the positive benefits of digitalization, and it is mandatory to remove mythical beliefs of digitalization from the people's mindset. 


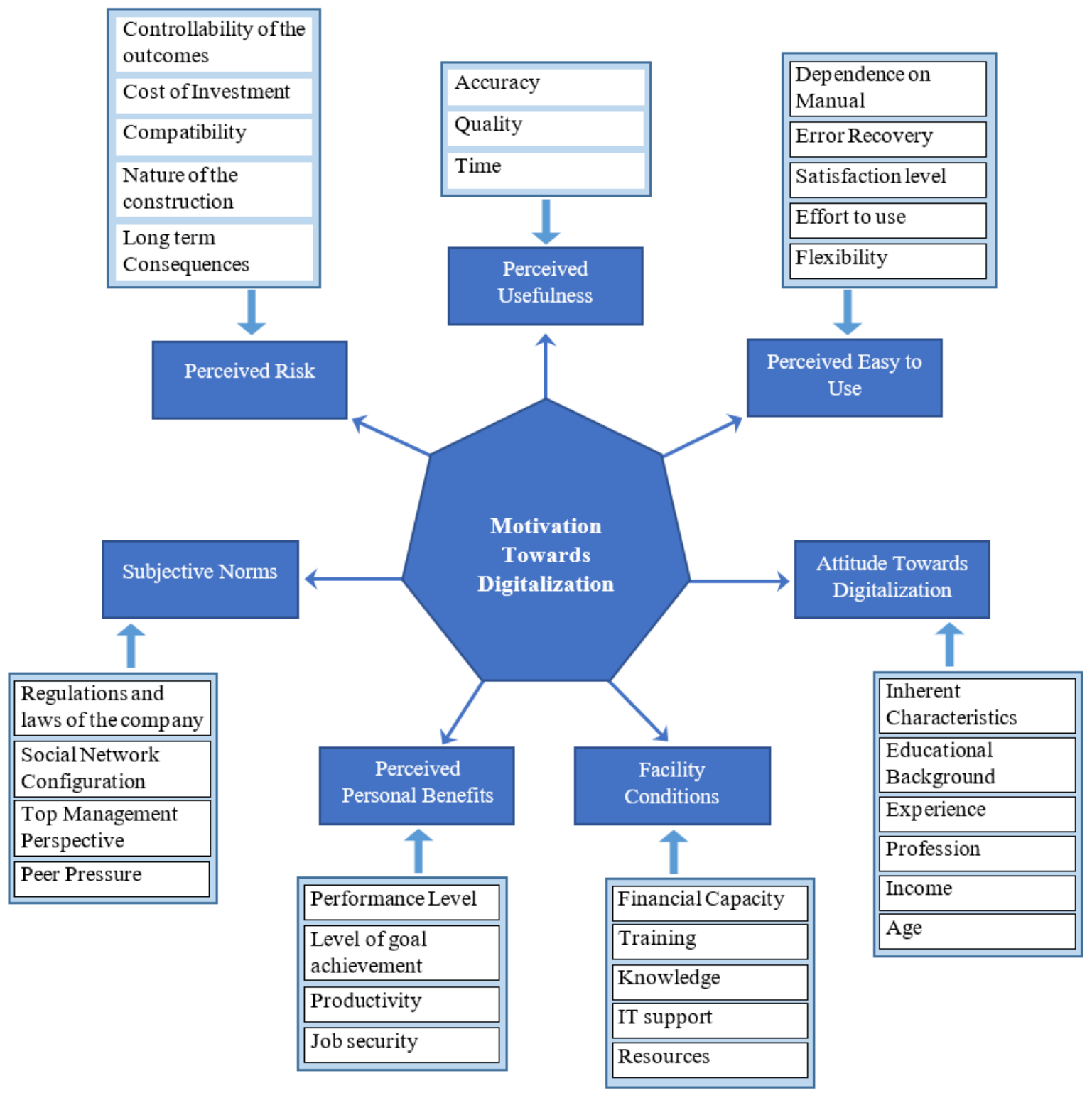

Figure 2. Factors associated with constraints.

Perceived risk associated with digitalization is based on the nature of the construction industry. There is a high probability that digitalization does not work for the construction industry because of its unique features, which are different from other industries, such as manufacturing, automobile, airline, hospitality, and others. However, there are a number of success stories that have overcome the obstacles properly and achieved success. Construction industries' most significant challenge is the shortage of skilled laborers and improper trade-off data. Digitalization would be ideal for these two cases unless it is more concentrated on cultural impact and human resistance. According to Interviewee 6, "The biggest threat in digital transformation in the construction industry generates because of the labor shortage in the industry".

Moreover, if the industry relies on excel spreadsheets, then the mentality is not stable regarding decision-making as they have to rely on someone else's data. However, changing management is the hardest where the culture and the mindset of the people need to change. Senior-level commitment will play a great role in mitigating these issues.

In addition, construction companies should have equipped the facility you need to change conditions such as training, workshops, hardware, and software. If employees set their minds to work with technologies and management does not support them, they 
will quickly get tired of working. According to Interviewee 3, “Most of the construction companies in Sri Lanka are reluctant to go for high bandwidth of internet as they have to pay more. However, working with slow internet speed is daffy responsibility with Cloud ERPs like webERP. Also, as there is a high turnover of jobs, it is not easy to enroll one particular person for the job. I had to train five people from the beginning up to now to work with the webERP system, which is a tiring process". Therefore, it is necessary to keep enough technical staff and technical resources within the organizations to move toward digital transformation.

The "Easy to Handle" factor is a general concept for every technology. Nobody likes to work with advanced complex operating systems. Initially, it takes some time to adapt to new technology, and the user manual can be a guide to working with technologies. However, if this training time gets longer and longer, there is a high probability of losing the systems from the user's hand.

According to Interviewee 2, "You cannot define an exact period when the construction industry gets digitalized until people will switch their mindset. It is much difficult to alter the traditional mindset of the people even top management in some leading construction companies. Therefore, before counting on digitalization in a construction organization, the first step should be to change the mentality of the end-users who use the technologies and make a positive feeling towards using them". This empathizes the importance of restricting the resistance from the human. Some people will like digital transformation, and some will not. Some will try to resist, and some people will not embrace it. So, the whole thing would be the psychology of the people, which is one of the biggest challenges.

According to the overall expert judgment, social influence plays a minor role in the digitalization in the construction industry. However, according to Interviewee 6, in "Multiplex", the leader's commitment has the highest impact on the success of digitalization in the organization.

\section{Conclusions}

There is plenty of research that focuses on digitalization and technology acceptance. However, none of the research has focused on digitalization within the construction industry. Identification of these factors will resolve the restrictions towards digitalization. This paper studied eight models, namely Theory of Reasoned Action (TRA), Theory of Planned Behavior (TPB), Theory of Technology Acceptance (TAM), Combined Theory of Technology Acceptance and Theory of Planned Behavior (C-TAM-TPB), Motivational model, Social cognitive theory, Diffusion Innovation Theory (DIT) and their latest derivation UTAUT model which were used to explain the acceptance of technologies by the end-user. As none of these models were specifically derived for the construction industry, a new model had to be developed incorporating specific features of the construction industry for digital transformation. The conceptual model consisted of four primary constraints which are common to IT acceptance, such as Perceived Easy to Use (PE), Perceived Usefulness (PU), Subjective Norms (SN), and Facility Condition (FC). Other than these four, three other parameters were introduced relating to the construction industry-Perceived Personal Benefits, Perceived Risk, and Perceived Attitudes. The impact of each constraint on the actual usage was investigated through expert judgments, and Perceived Personal Benefit was recorded as the most influencing factor for the digitalization of the construction industry according to the analytic hierarchy process (AHP) analysis. Further, as this conceptual model was derived from literature, empirical validation was carried out to validate the model using expert judgments.

As there is no research evidence for the digital transformation in the construction industry with respect to human factors, this research will provide insight into the key factors that should be considered with the digital transformation. Thus, this research fulfills the lack of knowledge in the digitalization of the construction industry as per the human perspective and will provide a prerequisite to finding the solutions for the issues which emerge within the industry toward digitalization. 
However, users in the construction field are not able to use these systems easily because of a lack of experience, revitalization in the use of different technologies, and the opinion that the construction site environment is continuously changing and that the actual efficiency cannot match the functionality of the programs. Other problems, such as lack of skill, program compatibility, instance of use, and application scope, need to be investigated. To solve the identified problems, the subjects of construction IT have to be more specific, and it is necessary to compare them with those in other industries. Future studies must examine the external variables and moderating factors of information technology acceptance and usage in the construction industry. Then, digitalization decisions in the construction industry can be made more systematically and rationally in the future with those outcomes. Furthermore, the research would like to propose longitudinal studies than cross-sectional research to obtain precise results for future studies.

Author Contributions: Conceptualization, T.H., S.N., P.P. and A.P.; methodology, T.H.; formal analysis, T.H.; investigation, T.H.; resources, T.H. and A.P.; data curation, T.H.; writing-original draft preparation, T.H.; software, T.H.; project administration, S.N.; writing-review and editing, T.H., S.N. and P.P.; visualization, T.H. and S.N.; supervision, A.P. All authors have read and agreed to the published version of the manuscript.

Funding: This research received no external funding.

Institutional Review Board Statement: Not applicable.

Informed Consent Statement: Not applicable.

Conflicts of Interest: The authors declare no conflict of interest.

Appendix A

Table A1. Constraints based on literature review.

\begin{tabular}{|c|c|c|c|}
\hline Factor & Definition & Application & Referred Model \\
\hline \multirow[t]{2}{*}{$\begin{array}{l}\text { Perceived Usefulness } \\
\text { (PU) }\end{array}$} & \multirow[t]{2}{*}{$\begin{array}{l}\text { PU measures the degree to which } \\
\text { an individual believes that using } \\
\text { the technology will help them } \\
\text { attain benefits }\end{array}$} & $\begin{array}{c}\text { Internet banking in Lebanon [31]. } \\
\text { Mobile learning adoption in higher } \\
\text { education in Guyana [55]. } \\
\text { Emirati Citizens' adoption of } \\
\text { e-Government in Abu Dhabi [56]. } \\
\text { Internet Banking Adoption [55]. } \\
\text { Acceptance of medical laboratory portals } \\
\text { by patients in Shiraz [79]. } \\
\text { Telecentre acceptance in Nigeria [38]. } \\
\text { Consumer acceptance of information } \\
\text { technology [51]. }\end{array}$ & UTAUT \\
\hline & & $\begin{array}{l}\text { Acceptance of information } \\
\text { technology [33]. } \\
\text { Acceptance of information } \\
\text { technology [32]. }\end{array}$ & TAM \\
\hline \multirow[t]{2}{*}{$\begin{array}{l}\text { Perceived Ease of Use } \\
\text { (PE) }\end{array}$} & \multirow[t]{2}{*}{$\begin{array}{l}\text { PE is the degree of ease associated } \\
\text { with customers' use of technology }\end{array}$} & $\begin{array}{c}\text { Internet banking in Lebanon [31]. } \\
\text { Mobile learning adoption in higher } \\
\text { education in Guyana [80]. } \\
\text { Emirati Citizens' adoption of } \\
\text { e-Government in Abu Dhabi [56]. } \\
\text { Internet banking adoption [81]. } \\
\text { Acceptance of medical laboratory portals } \\
\text { by patients in Shiraz [79]. } \\
\text { Telecentre acceptance in Nigeria [82]. } \\
\text { Consumer acceptance of information } \\
\text { technology [51]. }\end{array}$ & UTAUT \\
\hline & & $\begin{array}{l}\text { Acceptance of information } \\
\text { technology [33]. } \\
\text { Acceptance of information } \\
\text { technology [14]. }\end{array}$ & TAM \\
\hline
\end{tabular}


Table A1. Cont.

\begin{tabular}{|c|c|c|c|}
\hline Factor & Definition & Application & Referred Model \\
\hline Complexity & $\begin{array}{c}\text { Complexity is the extent to which } \\
\text { an innovation can be considered } \\
\text { relatively } \\
\text { difficult to understand and use }\end{array}$ & $\begin{array}{l}\text { Mobile banking adoption [83]. } \\
\text { Mobile banking adoption [55]. }\end{array}$ & $\begin{array}{c}\text { DIT } \\
\text { PC } \\
\text { Utilization Theory }\end{array}$ \\
\hline \multirow[t]{4}{*}{ Subjective Norms } & \multirow[t]{4}{*}{$\begin{array}{l}\text { SN is defined as "a person's } \\
\text { perception that most people who } \\
\text { are important to him think he } \\
\text { should or should not perform the } \\
\text { behavior in question" }\end{array}$} & $\begin{array}{l}\text { Mobile learning adoption in higher } \\
\text { education in Guyana [67]. } \\
\text { Emirati citizens' adoption of } \\
\text { e-Government in Abu Dhabi [56]. } \\
\text { Internet banking adoption [55]. } \\
\text { Acceptance of medical laboratory } \\
\text { portals by patients in Shiraz [79]. } \\
\text { Telecentre acceptance in Nigeria [84]. } \\
\text { Consumer acceptance of information } \\
\text { technology [51]. }\end{array}$ & UTAUT \\
\hline & & Technology adoption [45]. & TRA \\
\hline & & $\begin{array}{l}\text { Technology adoption [45]. } \\
\text { Technology adoption [21]. }\end{array}$ & TPB \\
\hline & & Mobile banking adoption [55]. & C-TAM-TPB \\
\hline \multirow{3}{*}{$\begin{array}{c}\text { Facility Conditions } \\
\text { (Barriers to implementing, } \\
\text { System Design } \\
\text { Characteristics, Top } \\
\text { management support, } \\
\text { training for staff, } \\
\text { decision-making } \\
\text { characteristics) }\end{array}$} & \multirow[t]{3}{*}{$\begin{array}{l}\text { The degree to which an individual } \\
\text { believes that an organizational } \\
\text { and technical infrastructure exists } \\
\text { to support the use of the system }\end{array}$} & $\begin{array}{l}\text { Internet banking in Lebanon [31]. } \\
\text { Emirati citizens' adoption of } \\
\text { e-Government in Abu Dhabi [56]. } \\
\text { Internet banking adoption [55]. } \\
\text { Acceptance of medical laboratory } \\
\text { portals by patients in Shiraz [79]. } \\
\text { Telecentre acceptance in Nigeria [38]. } \\
\text { Consumer acceptance of information } \\
\text { technology [51]. }\end{array}$ & UTAUT \\
\hline & & $\begin{array}{l}\text { Information and technology } \\
\text { acceptance [33]. }\end{array}$ & TAM \\
\hline & & Internet banking adoption [55]. & PC Utilization \\
\hline Management Effectiveness & $\begin{array}{l}\text { Management actions regarding } \\
\text { the organizational issues and staff } \\
\text { within the organization }\end{array}$ & Telecentre acceptance in Nigeria [38]. & Extended UTAUT \\
\hline Program Effectiveness & $\begin{array}{l}\text { Program is defined as the specific } \\
\text { service or intervention provided } \\
\text { by the organization with the } \\
\text { technology }\end{array}$ & Telecentre acceptance in Nigeria [38]. & Extended UTAUT \\
\hline \multirow[t]{2}{*}{$\begin{array}{l}\text { Perceived risk } \\
\text { (Price Value) }\end{array}$} & \multirow{2}{*}{$\begin{array}{l}\text { Perceived risk is the uncertainty } \\
\text { associated with the purchasing } \\
\text { and maintaining }\end{array}$} & $\begin{array}{c}\text { Consumer acceptance of information } \\
\text { technology [51]. }\end{array}$ & Extended UTAUT \\
\hline & & Mobile banking adoption [83]. & DIT \\
\hline Observability & $\begin{array}{l}\text { Observability is the extent to } \\
\text { which an innovation is visible to } \\
\text { the members of a social system, } \\
\text { and the benefits can be easily } \\
\text { observed and communicated }\end{array}$ & Mobile banking adoption [83]. & DIT \\
\hline Relative advantage & $\begin{array}{l}\text { Relative advantage refers to the } \\
\text { degree to which an innovation is } \\
\text { perceived as providing more } \\
\text { benefits than its Predecessor }\end{array}$ & Mobile banking adoption [83]. & DIT \\
\hline \multirow{4}{*}{ Individual believes } & \multirow{4}{*}{$\begin{array}{l}\text { Beliefs can be defined as long } \\
\text { term practiced convictions in } \\
\text { people's minds regarding a } \\
\text { particular technology }\end{array}$} & Technology adoption [45]. & TRA \\
\hline & & Telecentre acceptance in Nigeria [38]. & SCT \\
\hline & & Technology adoption [45]. & \\
\hline & & Technology adoption [21]. & \\
\hline
\end{tabular}


Table A1. Cont.

\begin{tabular}{|c|c|c|c|}
\hline Factor & Definition & Application & Referred Model \\
\hline Perceived credibility & $\begin{array}{l}\text { PC is the degree to which } \\
\text { competent trustworthiness is } \\
\text { given to the recipient. }\end{array}$ & $\begin{array}{l}\text { Internet banking in Lebanon [31]. } \\
\text { Emirati citizens' adoption of } \\
\text { e-Government in Abu Dhabi [56]. }\end{array}$ & Extended UTAUT \\
\hline Trialability & $\begin{array}{l}\text { The capacity to experiment with } \\
\text { new technology before adoption }\end{array}$ & Mobile banking adoption [83]. & DIT \\
\hline \multirow{2}{*}{ Task Technology Fit } & \multirow{2}{*}{$\begin{array}{c}\text { TTF is the degree to which the } \\
\text { technology fits with the task of an } \\
\text { individual }\end{array}$} & Internet banking in Lebanon [31]. & Extended UTAUT \\
\hline & & Mobile banking adoption [55]. & PC Utilization Theory \\
\hline $\begin{array}{l}\text { Compatibility with user } \\
\text { expectations }\end{array}$ & $\begin{array}{c}\text { The degree to which a service is } \\
\text { perceived as consistent with users' } \\
\text { existing values, beliefs, habits, } \\
\text { and present and previous } \\
\text { experiences }\end{array}$ & $\begin{array}{l}\text { Mobile banking adoption [83]. } \\
\text { Technology adoption [45]. }\end{array}$ & DIT \\
\hline Demonstrability & $\begin{array}{c}\text { The degree to which a technology } \\
\text { can be demonstrated and logically } \\
\text { proven. }\end{array}$ & Internet banking adoption [55]. & Extended UTAUT \\
\hline \multirow{2}{*}{$\begin{array}{c}\text { External Factors (Cultural, } \\
\text { Social and Political } \\
\text { Factors/Skills } \\
\text { (Educational Level), } \\
\text { Environmental } \\
\text { Conditions/Long Term } \\
\text { Consequences/Cost of the } \\
\text { Technol- } \\
\text { ogy/Age/Gender/Location) }\end{array}$} & \multirow{2}{*}{$\begin{array}{c}\text { The degree to which a technology } \\
\text { is influenced by external } \\
\text { interferences. }\end{array}$} & $\begin{array}{l}\text { Acceptance of information technology } \\
\text { [33]. }\end{array}$ & TAM \\
\hline & & Telecentre acceptance in Nigeria [15]. & SCT \\
\hline \multirow{2}{*}{ Motivational Factors } & \multirow{2}{*}{$\begin{array}{l}\text { The pleasure derived using a } \\
\text { technology }\end{array}$} & Technology adoption [45]. & TRA \\
\hline & & $\begin{array}{l}\text { Consumer acceptance of information } \\
\text { technology [51]. }\end{array}$ & Motivational Model \\
\hline \multirow{2}{*}{ Perceived enjoyment } & \multirow{2}{*}{$\begin{array}{l}\text { The extent to which an activity is } \\
\text { perceived to be enjoyable without } \\
\text { considering any performance } \\
\text { consequences }\end{array}$} & Computer game acceptance [35]. & TAM \\
\hline & & Internet banking adoption [55]. & Motivational Model \\
\hline \multirow{3}{*}{$\begin{array}{l}\text { Personal Factors (Anxiety, } \\
\text { Expectations, } \\
\text { Self-Perception, Individual } \\
\text { goal/habits) }\end{array}$} & \multirow{3}{*}{$\begin{array}{l}\text { Evolving anxious or emotional } \\
\text { reactions when it comes to } \\
\text { performing a behavior (e.g., using } \\
\text { a computer) the apprehension, or } \\
\text { even the fear an individual has } \\
\text { toward the possibility to use a } \\
\text { technology }\end{array}$} & Telecentre acceptance in Nigeria [38]. & $\mathrm{SCT}$ \\
\hline & & Technology adoption [21]. & $\mathrm{TPB}$ \\
\hline & & $\begin{array}{l}\text { Technology adoption in higher } \\
\text { education sector in Sri Lanka [37]. }\end{array}$ & UTAUT \\
\hline \multirow{2}{*}{$\begin{array}{l}\text { Perceived Behavioral } \\
\text { Control }\end{array}$} & \multirow{2}{*}{$\begin{array}{l}\text { The level of control the } \\
\text { consequences }\end{array}$} & Technology adoption [21]. & $\mathrm{TPB}$ \\
\hline & & Mobile banking adoption [55]. & C-TAM-TPB \\
\hline \multirow{4}{*}{ Attitude towards usage } & \multirow{4}{*}{$\begin{array}{c}\text { The individual's positive or } \\
\text { negative feeling (evaluative effect) } \\
\text { about performing the targeted } \\
\text { behavior }\end{array}$} & Technology adoption [45]. & TRA \\
\hline & & Technology adoption [21]. & $\mathrm{TPB}$ \\
\hline & & Computer game acceptance [35]. & TAM \\
\hline & & $\begin{array}{l}\text { Mobile learning adoption in higher } \\
\text { education in Guyana [80]. }\end{array}$ & UTAUT \\
\hline \multirow{4}{*}{ Behavioral Intention } & \multirow{4}{*}{$\begin{array}{c}\text { The measure of one's intention to } \\
\text { perform a specified behavior }\end{array}$} & Technology adoption [45]. & TRA \\
\hline & & Technology adoption [21]. & $\mathrm{TPB}$ \\
\hline & & Computer game acceptance [35]. & TAM \\
\hline & & $\begin{array}{l}\text { Mobile learning adoption in higher } \\
\text { education in Guyana [80]. }\end{array}$ & UTAUT \\
\hline
\end{tabular}


Table A1. Cont.

\begin{tabular}{cccc}
\hline Factor & Definition & Application & Referred Model \\
\hline & & Technology adoption [21]. & TPB \\
\cline { 2 - 4 } Personal Development & $\begin{array}{c}\text { The degree to which a person will } \\
\text { improve their self-development }\end{array}$ & $\begin{array}{c}\text { Information and technology } \\
\text { acceptance [33]. }\end{array}$ & TAM \\
\cline { 3 - 4 } & & $\begin{array}{c}\text { Mobile learning adoption in higher } \\
\text { education in Guyana [80]. }\end{array}$ & UTAUT \\
\hline
\end{tabular}

\section{References}

1. Sbiti, M.; Beddiar, K.; Beladjine, D.; Perrault, R.; Mazari, B. Toward BIM and LPS Data Integration for Lean Site Project Management: A State-of-the-Art Review and Recommendations. Buildings 2021, 11, 196. [CrossRef]

2. Hewavitharana, T.; Perera, A.; Nanayakkara, S. Prioritizing Enterprise Resource Planning (ERP) Systems for Small and Medium Enterprises. Res. J. 2019, 5, 1-7.

3. Nanayakkara, S.; Perera, S.; Senaratne, S. Stakeholders' Perspective on Blockchain and Smart Contracts Solutions for Construction Supply Chains. In Proceedings of the CIB World Building Congress, Hong Kong, 17-21 June 2019.

4. Nanayakkara, S.; Perera, S.; Senaratne, S.; Weerasuriya, G.T.; Bandara, H.M.N.D. Blockchain and Smart Contracts: A Solution for Payment Issues in Construction Supply Chains. Informatics 2021, 8, 36. [CrossRef]

5. Calvetti, D.; Mêda, P.; Chichorro Gonçalves, M.; Sousa, H. Worker 4.0: The future of sensored construction sites. Buildings 2020, 10, 169. [CrossRef]

6. Nanayakkara, S.; Perera, P.; Perera, A. Factors Influencing Selection and Effective Implementation of ERP Systems in Medium Sized Organizations in Developing Countries. Int. J. Comput. Internet Manag. 2013, 21, 7-14.

7. Nanayakkara, S.; Perera, P.; Perera, A. Factors Incompatibility of Selection and Implementation of ERP Systems for Construction Organizations. Int. J. Comput. Sci. Technol. 2015, 6, 9-15.

8. Hewavitharana, T.; Nanayakkara, S.; Perera, A.; Perera, J. Impact of Enterprise Resource Planning (ERP) Systems to the Construction Industry. Int. J. Res. Electron. Comput. Eng. 2019, 7, 887-893.

9. Elagiry, M.; Marino, V.; Lasarte, N.; Elguezabal, P.; Messervey, T. BIM4Ren: Barriers to BIM implementation in renovation processes in the Italian market. Buildings 2019, 9, 200. [CrossRef]

10. Berlak, J.; Hafner, S.; Kuppelwieser, V.G. Digitalization's impacts on productivity: A model-based approach and evaluation in Germany's building construction industry. Prod. Plan. Control 2021, 32, 335-345. [CrossRef]

11. Attuquayefio, S.; Addo, H. Using the UTAUT model to analyze students' ICT adoption. Int. J. Educ. Dev. Using ICT 2014, 10, 75-86.

12. Al Awadhi, S.; Morris, A. The Use of the UTAUT Model in the Adoption of E-government Services in Kuwait. In Proceedings of the 41st Annual Hawaii International Conference on System Sciences (HICSS 2008), Waikoloa, HI, USA, 7-10 January 2008 ; p. 219.

13. Armenia, S.; Casalino, N.; Gnan, L.; Flamini, G. A systems approach to the digital transformation of public administration. Prospett. Organ. 2021, 14, 1-19.

14. Davis, F.D. User acceptance of information technology: System characteristics, user perceptions and behavioral impacts. Int. J. Man-Mach. Stud. 1993, 38, 475-487. [CrossRef]

15. Waluyani, R.C.; Subroto, B.; Purnomosidhi, B. Effect of External Factors of Technology Acceptance Model toward Technology Acceptance of Online Travel Agent. J. Econ. 2018, 14, 158-176. [CrossRef]

16. Chanias, S.; Myers, M.D.; Hess, T. Digital transformation strategy making in pre-digital organizations: The case of a financial services provider. J. Strateg. Inf. Syst. 2019, 28, 17-33. [CrossRef]

17. Morgan, B. Organizing for digitalization through mutual constitution: The case of a design firm. Constr. Manag. Econ. 2019, 37, 400-417. [CrossRef]

18. Begić, H.; Galić, M. A Systematic Review of Construction 4.0 in the Context of the BIM 4.0 Premise. Buildings 2021, 11, 337. [CrossRef]

19. Hewavitharana, T.; Nanayakkara, S.; Perera, S. Blockchain as a project management platform. In Proceedings of the World Construction Symposium, Colombo, Sri Lanka, 8-10 July 2021; pp. 137-146.

20. Jensson, A. Digitalization in the Construction Industry. Master's Thesis, Chalmers University of Technology, Gothenburg, Sweden, 2017.

21. Ajzen, I. The theory of planned behavior. Organ. Behav. Hum. Decis. Process. 1991, 50, 179-211. [CrossRef]

22. Khater, A.H.O. Customers' Acceptance of Internet Banking Service in Sudan by Using Unified Theory of Acceptance and Use of Technology (UTAUT) Model. PhD Thesis, Sudan University of Science and Technology, Khartoum, Sudan, 2016.

23. Hale, J.L.; Householder, B.J.; Greene, K.L. The theory of reasoned action. Persuas. Handb. Dev. Theory Pract. 2002, 14, $259-286$.

24. Fishbein, M. A theory of reasoned action: Some applications and implications. Neb. Symp. Motiv. 1979, $27,65-116$.

25. Chuchinprakarn, S. Application of the theory of reasoned action to on-line shopping. Knowl. Cent. E-Pap. Bangk. Univ. 2005, 1-7. Available online: https:/ / citeseerx.ist.psu.edu/viewdoc/download?doi=10.1.1.527.4799\&rep=rep1\&type=pdf (accessed on 18 November 2021). 
26. Nor, K.M.; Shanab, E.A.A.; Pearson, J.M. Internet banking acceptance in Malaysia based on the theory of reasoned action. Jistem-J. Inf. Syst. Technol. Manag. 2008, 5, 3-14.

27. Davis Fred, D.; Bagozzi Richard, P.; Warshaw Paul, R. User acceptance of computer technology: A comparison of two theoretical models. Manag. Sci. 1989, 35, 982-1003. [CrossRef]

28. Olabanji, O. Exploring the application of information security governance in mitigating insider negligence threats: A qualitative analysis. Ph.D. Thesis, Capella University, Minneapolis, MN, USA, 2019.

29. Sniehotta, F.F.; Presseau, J.; Araújo-Soares, V. Time to retire the theory of planned behaviour. Health Psychol. Rev. 2014, 8, 1-7. [CrossRef] [PubMed]

30. Ajzen, I. The Theory of Planned Behaviour: Reactions and Reflections; Taylor \& Francis: Oxfordshire, UK, 2011.

31. Thomas, T.; Singh, L.; Gaffar, K. The utility of the UTAUT model in explaining mobile learning adoption in higher education in Guyana. Int. J. Educ. Dev. Using ICT 2013, 9, 71-85.

32. Davis, F.D. Perceived usefulness, perceived ease of use, and user acceptance of information technology. Mis Q. 1989, 13, 319-340. [CrossRef]

33. Surendran, P. Technology acceptance model: A survey of literature. Int. J. Bus. Soc. Res. 2012, 2, 175-178.

34. Khan, M.I.; Saleh, M.A.; Quazi, A. Social Media Adoption by Health Professionals: A TAM-Based Study. Informatics 2021, 8, 6. [CrossRef]

35. Chen, H.; Rong, W.; Ma, X.; Qu, Y.; Xiong, Z. An extended technology acceptance model for mobile social gaming service popularity analysis. Mob. Inf. Syst. 2017, 2017, 3906953. [CrossRef]

36. Lokuge, S.; Sedera, D.; Nanayakkara, S. Innovate or Copy: A Qualitative Document Analysis to Entrepreneurship in Developing Countries. In Proceedings of the 26th European Conference on Information Systems (ECIS2018), Portsmouth, UK, 23-28 June 2018.

37. Gunasinghe, A.; Nanayakkara, S. Role of technology Anxiety within UTAUT in understanding non-user adoption intentions to Virtual Learning Environments: The state university lecturers' perspective. Int. J. Technol. Enhanc. Learn. 2021, 13, 284-308. [CrossRef]

38. Abdulwahab, L.; Dahalin, Z.M. A conceptual model of Unified Theory of Acceptance and Use of Technology (UTAUT) modification with management effectiveness and program effectiveness in context of telecentre. Afr. Sci. 2021, 11, $267-275$.

39. Safeena, R.; Date, H.; Hundewale, N.; Kammani, A. Combination of TAM and TPB in internet banking adoption. Int. J. Comput. Theory Eng. 2013, 5, 146. [CrossRef]

40. Cheng, E.W. Choosing between the theory of planned behavior (TPB) and the technology acceptance model (TAM). Educ. Technol. Res. Dev. 2019, 67, 21-37. [CrossRef]

41. Schunk, D.H. Social Cognitive Theory; American Psychological Association: Washington, DC, USA, 2012.

42. Luszczynska, A.; Schwarzer, R. Social cognitive theory. In Predicting and Changing Health Behaviour: Research and Practice with Social Cognition Models; Conner, M., Ed.; McGraw-Hill Education: New York, NY, USA, 2015; pp. 225-251.

43. Bandura, A. Social cognitive theory in cultural context. Appl. Psychol. 2002, 51, 269-290. [CrossRef]

44. Dearing, J.W.; Cox, J.G. Diffusion of innovations theory, principles, and practice. Health Aff. 2018, 37, 183-190. [CrossRef]

45. Lai, P.C. The literature review of technology adoption models and theories for the novelty technology. JISTEM-J. Inf. Syst. Technol. Manag. 2017, 14, 21-38. [CrossRef]

46. Nanayakkara, S.; Kusumsiri, N.; Perera, P. Adaptation of Diffusion of Innovations Theory for Successful ERP Implementation. Int. J. Comput. Sci. Technol. 2016, 7, 2016.

47. Thompson, R.L.; Higgins, C.A.; Howell, J.M. Personal computing: Toward a conceptual model of utilization. Mis Q. 1991, 15, 125-143. [CrossRef]

48. Davis, F.D.; Bagozzi, R.P.; Warshaw, P.R. Extrinsic and intrinsic motivation to use computers in the workplace 1. J. Appl. Soc. Psychol. 1992, 22, 1111-1132. [CrossRef]

49. Abduljalil, K.M.; Zainuddin, Y. Integrating technology acceptance model and motivational model towards intention to adopt accounting information system. Int. J. Manag. Account. Econ. 2015, 2, 346-359.

50. Kayser, L.; Nøhr, C.; Bertelsen, P.; Botin, L.; Villumsen, S.; Showell, C.; Turner, P. Theory and practice in digital behaviour change: A matrix framework for the co-production of digital services that engage, empower and emancipate marginalised people living with complex and chronic conditions. Informatics 2018, 5, 41. [CrossRef]

51. Venkatesh, V.; Thong, J.Y.; Xu, X. Consumer acceptance and use of information technology: Extending the unified theory of acceptance and use of technology. Mis Q. 2012, 36, 157-178. [CrossRef]

52. Venkatesh, V.; Morris, M.G.; Davis, G.B.; Davis, F.D. User acceptance of information technology: Toward a unified view. Mis Q. 2003, 27, 425-478. [CrossRef]

53. Oye, N.; Iahad, N.A.; Rahim, N.A. The history of UTAUT model and its impact on ICT acceptance and usage by academicians. Educ. Inf. Technol. 2014, 19, 251-270. [CrossRef]

54. Holden, R.J.; Karsh, B.-T. The technology acceptance model: Its past and its future in health care. J. Biomed. Inform. 2010, 43, 159-172. [CrossRef]

55. Al-Qeisi, K.I. Analyzing the Use of UTAUT Model in Explaining an Online Behaviour: Internet Banking Adoption. Ph.D. Thesis, Brunel University Brunel Business School, London, UK, 2009. 
56. Al Mansoori, K.A. Use of a Modified UTAUT Model to Investigate Emirati Citizens' Adoption of e-Government in Abu Dhabi. DBA Thesis, University of Wollongong, Dubai, United Arab Emirates, 2017.

57. Im, I.; Hong, S.; Kang, M.S. An international comparison of technology adoption: Testing the UTAUT model. Inf. Manag. 2011, 48, 1-8. [CrossRef]

58. Chauhan, S.; Jaiswal, M. Determinants of acceptance of ERP software training in business schools: Empirical investigation using UTAUT model. Int. J. Manag. Educ. 2016, 14, 248-262. [CrossRef]

59. Kim, S.; Lee, K.-H.; Hwang, H.; Yoo, S. Analysis of the factors influencing healthcare professionals' adoption of mobile electronic medical record (EMR) using the unified theory of acceptance and use of technology (UTAUT) in a tertiary hospital. Bmc Med Inform. Decis. Mak. 2015, 16, 1-12. [CrossRef]

60. Foon, Y.S.; Fah, B.C.Y. Internet banking adoption in Kuala Lumpur: An application of UTAUT model. Int. J. Bus. Manag. 2011, 6, 161.

61. Saaty, T.L. What is the analytic hierarchy process? In Mathematical Models for Decision Support; Springer: New York, NY, USA, 1988; pp. 109-121.

62. Hsu, W.-L.; Tsai, F.-M.; Shiau, Y.-C. Planning and assessment system for light rail transit construction in Taiwan. Microsyst. Technol. 2021, 27, 1051-1060. [CrossRef]

63. Saaty, T.L. Decision making with the analytic hierarchy process. Int. J. Serv. Sci. 2008, 1, 83-98. [CrossRef]

64. Saaty, T.L. How to make a decision: The analytic hierarchy process. Eur. J. Oper. Res. 1990, 48, 9-26. [CrossRef]

65. Tubaishat, A. Perceived usefulness and perceived ease of use of electronic health records among nurses: Application of technology acceptance model. Inform. Health Soc. Care 2018, 43, 379-389. [CrossRef]

66. Lee, Y.; Lee, J.; Lee, Z. Social influence on technology acceptance behavior: Self-identity theory perspective. ACM SIGMIS Database Database Adv. Inf. Syst. 2006, 37, 60-75. [CrossRef]

67. Benešová, A.; Tupa, J. Requirements for education and qualification of people in Industry 4.0. Procedia Manuf. 2017, 11, 2195-2202. [CrossRef]

68. Woodhead, R.; Stephenson, P.; Morrey, D. Digital construction: From point solutions to IoT ecosystem. Autom. Constr. 2018, 93, 35-46. [CrossRef]

69. Zhou, J. Digitalization and intelligentization of manufacturing industry. Adv. Manuf. 2013, 1, 1-7. [CrossRef]

70. Perera, S.; Nanayakkara, S.; Rodrigo, M.; Senaratne, S.; Weinand, R. Blockchain Technology: Is it Hype or Real in the Construction Industry? J. Ind. Inf. Integr. 2020, 17, 1-20. [CrossRef]

71. Maamuom, M.A.; Satria, M.H.; Supriyanto, E.; Yunus, J. Exploring Factors Influencing 'Perceived Usefulness' and Its Relationship on Hospital Information System End User Satisfaction. Recent Advances on Computational Science and Applications. 2013. Available online: http:/ / www.wseas.us/e-library/conferences/2015/Seoul/ACME/ACME-21.pdf (accessed on 25 October 2021).

72. Guritno, S.; Siringoringo, H. Perceived usefulness, ease of use, and attitude towards online shopping usefulness towards online airlines ticket purchase. Procedia-Soc. Behav. Sci. 2013, 81, 212-216.

73. Silic, M.; Back, A. Organizational Culture Impact on Acceptance and Use of Unified Communications \& Collaboration Technology in Organizations. In Proceedings of the Bled eConference, Bled, Slovenia, 9-13 June 2013; p. 28.

74. Brown, I.T. Individual and technological factors affecting perceived ease of use of web-based learning technologies in a developing country. Electron. J. Inf. Syst. Dev. Ctries. 2002, 9, 1-15. [CrossRef]

75. Kennedy, D.; Hyland, Á.; Ryan, N. Learning outcomes and competences. Introd. Bologna Object. Tools $2009,2,3$.

76. Sørheller, V.U.; Høvik, E.J.; Hustad, E.; Vassilakopoulou, P. Implementing cloud ERP solutions: A review of sociotechnical concerns. Procedia Comput. Sci. 2018, 138, 470-477. [CrossRef]

77. Zhang, Z.; Hou, Y. The effect of perceived risk on information search for innovative products and services: The moderating role of innate consumer innovativeness. J. Consum. Mark. 2017, 34, 241-254. [CrossRef]

78. Rose, J.; Fogarty, G.J. Determinants of perceived usefulness and perceived ease of use in the technology acceptance model: Senior consumers' adoption of self-service banking technologies. In Proceedings of the 2nd Biennial Conference of the Academy of World Business, Marketing and Management Development: Business Across Borders in the 21st Century, Paris, France, 10-13 July 2006; pp. 122-129.

79. Ravangard, R.; Kazemi, Z.; Abbasali, S.Z.; Sharifian, R.; Monem, H. Development of the UTAUT2 model to measure the acceptance of medical laboratory portals by patients in Shiraz. Electron. Physician 2017, 9, 3862. [CrossRef] [PubMed]

80. Leclercg-Vandelannoitte, A. Information technology \& people article information. Inf. Technol. People 2015, 28 , 2-33.

81. Al-Qeisi, K.; Hegazy, A. Consumer online behaviour: A perspective on Internet banking usage in three non-western countries. Procedia Econ. Financ. 2015, 23, 386-390. [CrossRef]

82. Chiemeke, S.; Evwiekpaefe, A.; Okpo, J.; Irhebhude, M. A framework for electronic commerce adoption: A study in Kaduna state, Nigeria. Sci. World J. 2014, 9, 20-26.

83. Al-Jabri, I.M.; Sohail, M.S. Mobile banking adoption: Application of diffusion of innovation theory. J. Electron. Commer. Res. 2012, 13, 379-391.

84. Evans, O. Digital agriculture: Mobile phones, internet \& agricultural development in Africa. Actual Probl. Econ. 2018, 7-8, 76-90. 